Agricultural Journal 6 (3): 92-99, 2011

ISSN: $1816-9155$

(C) Medwell Journals, 2011

\title{
Seasonality and Crop Combination Effects on Growth and Yield of Two Sorghum (Sorghum bicolor) Cultivars in Sorghum/Maize/Okra Intercropin a Forest-Savanna Transition Zone of Nigeria
}

\author{
${ }^{1}$ A.A. Makinde, ${ }^{2}$ N. J. Bello, ${ }^{3}$ F.O. Olasantan, ${ }^{4}$ M.A. Adebisi and ${ }^{1}$ H.A. Adeniyi \\ ${ }^{1}$ Farming Systems and Extension Programme, \\ National Horticultural Research Institute, Ibadan, Nigeria \\ ${ }^{2}$ Department of Water Resources Management and Agrometeorology, \\ ${ }^{3}$ Department of Horticulture, ${ }^{4}$ Department of Plant Breeding and Seed Technology, \\ University of Agriculture, Abeokuta, Nigeria
}

\begin{abstract}
Seasonality and crop combination effects performance of two sorghum cultivars in sorghum/maize/okra intercrop in a forest-savanna transition zone of Nigeria was investigated. Total 5 phenological stages of sorghum formed the basic unit of time for the investigation. During these phenological stages, agroclimatological indices were measured daily and processed into 10 days averages likewise selected agronomic parameters of the components crops were taken. The plants were intercropped in simple Randomized Complete Block Design (RCBD) fitted into split plot arrangements with three replicates in two field trials. The results showed that the season 2010 crops had relatively longer growth duration, received more rainfall than season 2009 (692 vs. $487.2 \mathrm{~mm}$ ) while 2009 experienced warmer temperature during establishment cum early vegetative stage than 2010 season $\left(33.2\right.$ vs. $\left.32^{\circ} \mathrm{C}\right)$ and $\left(28.5\right.$ vs. $\left.27^{\circ} \mathrm{C}\right)$ during the reproductive phase for season 2009 and 2010 , respectively. The mean grain yields of sorghum cultivars were significantly higher in the season 2009 especially in okra combination than in the season 2010. Perhaps, this was due to higher mean soil temperature of 28 and $26^{\circ} \mathrm{C}$ at 5 and $20 \mathrm{~cm}$ in 2009 season compared with season 2010 when mean soil temperature was 27 and $25^{\circ} \mathrm{C}$ at 5 and $20 \mathrm{~cm}$, respectively.
\end{abstract}

Key words: Forest-savanna, sorghum, phenology, thermal indices, reproductive, phenological

\section{INTRODUCTION}

Seasonal weather variability has a direct influence on the quantity and quality of agricultural production in tropical Africa. Specifically in Nigeria, Agricultural production is at the mercy of weather which had been providing the opportunities to use agriculture for economic means most importantly the rural dwellers. It is for this reason among others that the farmers in the forest-savanna transition zone of Nigeria mostly practice intercropping since, there is more regular pattern of water availability in the zone. Intercropping which has been associated with such advantages as better utilization of environmental factors, greater yield stability, soil protection, variability of food supply increasing the return per unit area and insurance against crop failure (Beets, 1982). According to Adetunji (1993), intercropping using improved cultivars of crop and improved agronomic practices remains the most feasible approach to optimize crop production and maximize the use of available land. The common crop combinations in the zone include maize-cassava, maize-mellon and maize-okra intercrop, etc. but there is dearth of information on sorghum-okra and sorghum-maize intercrop in the zone. Sorghum is the most important cereal crop in Nigeria (Agboola, 1979). The crop is grown primarily for human consumption in the form of flour or used in the brewing of beer. It is usually grown by the subsistence farmers in rain fed as well as in irrigated. In some parts of the world, it is also consumed as staple food and is used for a variety of by-product like alcohol, edible oil, sugar, wax, etc. Its nutritional value is equal to that of corn (Whealer, 1950). In this context, the present study sorts to investigate the effect of season and crop combination on growth and yield of 2 sorghum cultivars in maize-sorghum-okra intercrop in a forest-savanna transition of Nigeria.

\section{MATERIALS AND METHODS}

The experiment was carried out at Experimental Teaching and Research Farmland of the National Horticultural Research Institutes (NIHORT), Ibadan

Corresponding Author: H.A. Adeniyi, Farming Systems and Extension Programme, National Horticultural Research Institute, Ibadan, Nigeria 
(Lat. $7^{\circ} 22^{\prime} \mathrm{N}$, Long. $3^{\circ} 50^{\prime} \mathrm{E}$ ) during the 2009 and 2010 cropping seasons. About 2 sorghum cultivars (Farin Dawa and Janare), one maize (Suwan-1) and okra (NHAe 47-4) cultivar were used in 2 field trails during 2009 and 2010 planting seasons. Between 3 and 4 seeds of sorghum, maize and okra were planted at a depth of $2.5 \mathrm{~cm}$. Sorghum was planted 3 weeks after planting okra and maize to enable okra and maize full establishment. Sorghum spacing was $90 \times 60 \mathrm{~cm}$ ( 2 seedlings $/$ stand), maize spacing was $90 \times 30 \mathrm{~cm}$ (1 seedling/stand) and okra spacing was $90 \times 30 \mathrm{~cm}$ ( 1 seedling/stand).

Each plot size was $6 \times 3 \mathrm{~m}$ making a total plot size of $100 \times 20 \mathrm{~m}$ plus walking paths. The plots were hand hoe and weeded manually at 3 and 6 weeks after planting. The experimental plots were arranged in a Randomize Complete Block Design (RCBD) fitted into split plot design with three replicates.

Data collection: During the phenological stages, 3 sets of data were collected and these were: Agrometeorological data of the plant micro environment measured from meteorological enclosure not far from the experimental site and growth and yield parameters of the three component crops.

Agrometeorological indices: Minimum and maximum temperature $\left(\mathrm{T},{ }^{\circ} \mathrm{C}\right.$ ), wind speed (Ws at a height of $2 \mathrm{~m}$ $\left.\left(\mathrm{m} \mathrm{sec}^{-1}\right)\right)$ rainfall $(\mathrm{P}, \mathrm{mm})$ relative humidity $(\%)$ and sun shine hours all these variables were observed at a meteorological enclosure within the vicinity of the experimental field.

Growth parameters: The data were collected on the desired growth parameters of the components crops as per treatment by using standard procedures. Major growth parameters considered includes: plant height, leaf area and number of leaves of the components crops were measured starting 4 weeks after planting. These were determined by randomly selecting any 10 plant stands in each plot and these selected stands are monitored throughout the sampling period. Days to panicle initiation (sorghum), days to 1 st flowering (okra), days to $50 \%$ flowering (both sorghum and okra), days to 1st harvest (okra) were also observed and recorded.

Yield parameters: Yield parameters considered include grain yield (sorhum and maize), panicle length (sorghum) fresh cob weight (maize), weight of 100 seeds (maize), pods number/plot and pods weight, length and diameter of okra yield. Each of the parameters was determined by randomly selecting any 10 yield sample of each component crop and their means calculated.
Statistical analysis: Analyses of variance were carried out by established methods (Steel et al., 1997) using the PROC GLM procedure of the SAS Statistics package (SAS, 2000). The cropping pattern and cultivars were considered as random effects while the planting seasons were fixed effects. Cultivars and crop combination mean differences within each season were separated using Fishers' protected least significant difference (1.s.d.) test at $\mathrm{p} \leq 0.05$.

\section{RESULTS}

Weather conditions: Weather conditions for the growing seasons differed considerably at various stages of the crop growth. The 10 days values for rainfall, maximum and minimum temperature, relative humidity and wind speed for seasons 2009 and 2010 at National Horticultural Research Institute (NIHORT), Ibadan were related to the main phases of vegetative growth and reproductive development of sorghum in Fig. 1-3. Rainfall during stages of growth was much higher in 2010 cropping season than 2009 cropping season (i.e., 487.2 vs. $692 \mathrm{~mm}$ ). Consequently, rainfall during the vegetative growth

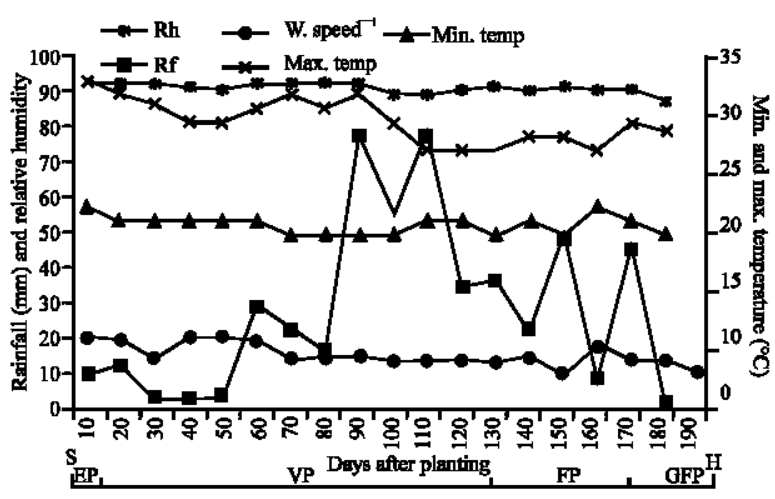

Fig. 1: Weather trend during the season 2009 (June to November) at NIHORT, Ibadan

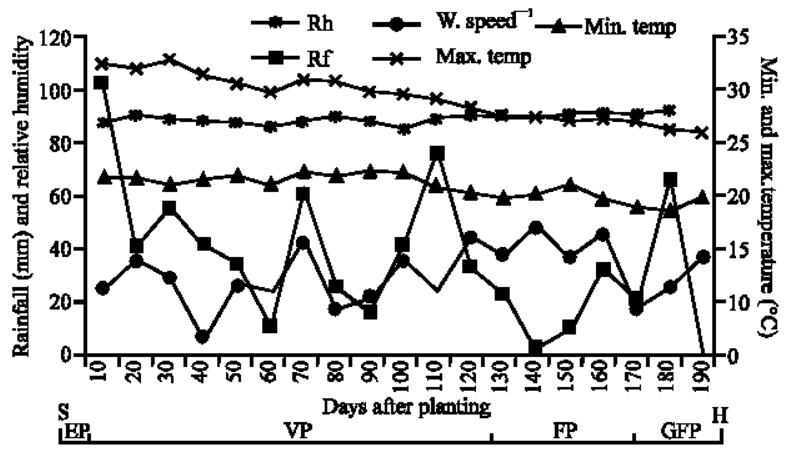

Fig. 2: Weather trend during the season 2009 (April to October) at NIHORT, Ibadan 


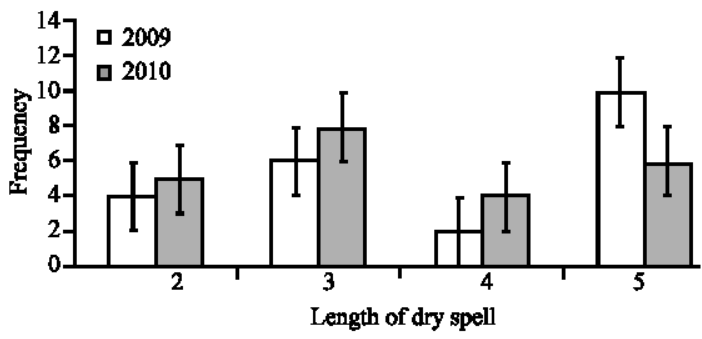

Fig. 3: Dry spell occurrence during the cropping season 2009 and 2010 at NIHORT, Ibadan

stages of sorghum was lower in the season 2009 than 2010 crops (i.e., 331.5 vs. $537.5 \mathrm{~mm}$ ). The same scenario was observed during the reproductive phase in season 2009 with $366.6 \mathrm{~mm}$ against $560.2 \mathrm{~mm}$ in season 2010 . Temperature also varied during the growth of sorghum in the 2 seasons (Fig. 2 and 3) and was similar in its distribution to that found elsewhere in the savanna region $\left(7^{\circ} 49^{\prime} \mathrm{N}, 6^{\circ} 03^{\prime} \mathrm{E}\right)$ of Nigeria (Olaniran and Babatolu, 1987). Minimum temperature varied between 22 and $24^{\circ} \mathrm{C}$ in 2009 season while it ranged between 21.2 and $23.4^{\circ} \mathrm{C}$ in 2010 season.

Maximum temperature ranged between 28 and $33^{\circ} \mathrm{C}$ in season 2009 while it range between 27 and $32^{\circ} \mathrm{C}$ in season 2010. Temperature were warmer during planting, establishment and early vegetative stages than during reproductive stage in season 2009 ( 24 vs. $22^{\circ} \mathrm{C}$ and 33 vs. $28^{\circ} \mathrm{C}$ ) and similar trend was observed in season 2010 ( 23 vs. $22^{\circ} \mathrm{C}$ and 31 vs. $27^{\circ} \mathrm{C}$ ).

The range of temperatures observed fell within the optimum temperature required for sorghum production (Caddel and Weibel, 1971; Downes, 1972; Purseglove, 1972; Quinby et al., 1973). Downes (1972) indicated that air temperatures above $30^{\circ} \mathrm{C}$ during vegetative stage delayed floral development, particularly initiation of panicle meristem.

Consequently, the vegetative phase became longer than usual and the grain yield was reduced. Further review of literature suggested that it is during the period from panicle initiation to anthesis that high temperature leads to reduction in the grain yield of sorghum through its shortening of the period of panicle development (Peacock and Wilson, 1984). In particular, supra-optimal temperatures may hasten flowering (Doggett, 1988) and reduce the length of the period between panicle initiation and anthesis. A reduction in this period caused by high temperature has in some cases been associated with reduced sorghum yields (Ogunlela, 1979).

Dry spell distribution pattern: Figure 3 showed frequency of dry spells of different magnitude during the cropping season of 2009 and 2010 . Figure 3 showed that

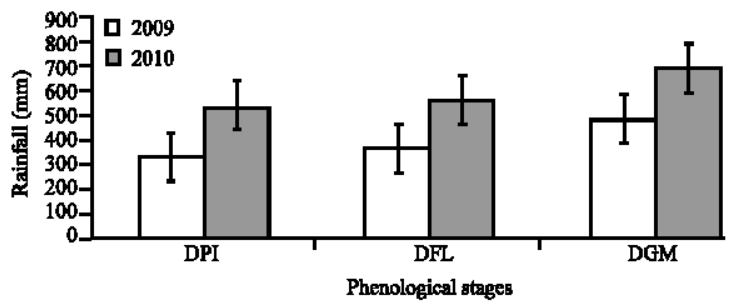

Fig. 4: Rainfall at major phenological stages at NIHORT, DPI: Days of Panicle Intiation; DFL: Days of Flowering; DGM: Days of Maturity, Ibadan in season 2009 and 2010

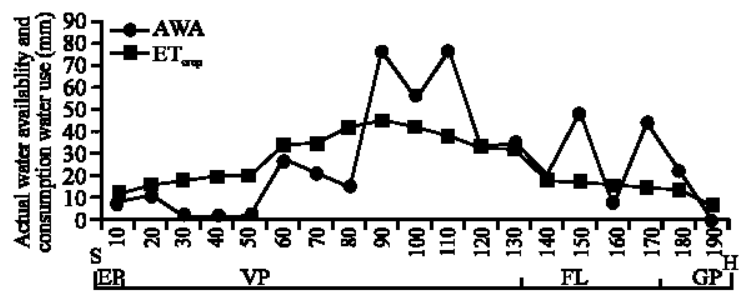

Fig. 5: Relationship between Actual Water Availabilty (AWA) and consumptive water use $\left(\mathrm{ET}_{\text {crop }}\right)$ by sorghum at NIHORT, Ibadan in cropping season 2009

during 2009 cropping season a 5 days dry spells had the highest frequency of 10 occasions followed by a 3 days dry spells of 6 occasions then 2 days dry spell with 4 occasions while 4 days dry spell had the lowest frequency of 2 occasions, however in season 2010 about 3 dry spell was the with a frequency of 8 followed by 5 days dry spell of 6 occasions then a 2 days dry spell of 5 occasions while the lowest value was registered under 4 days dry spell. The indication is that there are more dry days in 2009 cropping season than those experienced during 2010 cropping season.

Phenological rainfall distribution pattern: Result of Fig. 4 is rainfall amount recorded at various phenological stages. In season 2009, grain filling period recorded highest amount of rainfall $(487.2 \mathrm{~mm})$ followed by flowering period $(366.6 \mathrm{~mm})$ while least rainfall was recorded at panicle period $(331.5 \mathrm{~mm})$. Similar trend were observed for cropping season 2010 with grain filling period having $692 \mathrm{~mm}$ followed by flowering period with $560.2 \mathrm{~mm}$ while the least amount was recorded during panicle period with $537.5 \mathrm{~mm}$.

Moisture adequacy index: Figure 5 shows an investigation of moisture adequacy based on relationship between Actual Water Availability (AWA) and consumptive water use by sorghum $\left(\mathrm{ET}_{\text {crop }}\right)$ during the 2009 cropping season. Figure 5 shows that AWA was in 
excess of $\mathrm{ET}_{\text {cop }}$ from 80-190 days (110 days) after planting (DAP) whereas, $\mathrm{ET}_{\text {crop }}$ was in excess of AWA from planting to $60 \mathrm{DAP}$ ( 60 days) meaning that mooisture was surficient for about 110 days but moisture inadequate for just 60 days.

Figure 6 shows an investigation of moisture adequacy for sorghum based on relationship between AWA and $\mathrm{ET}_{\text {crop }}$ during the 2010 season. Figure 6 shows that AWA was consistently in excess of $\mathrm{ET}_{\text {crop }}$ in 2010 season by about 160 days except for period between 60-70 (10 days) and 130-140 DAP (10 days) when there were evidence of moisture deficiency. Although, the total amount and duration (20 days) of moisture deficiency appeared tolerabl. Jordan and Sullivan (1982) found that prolong moisture stress during vegetative period could inhibit vegetative growth. Leaf area is most affected by moisture stress which retards the photochemical and biochemical activities of the chloroplasts (Boyer, 1976). Cosequently, the crop's photosynthesis capacity is weakned invariably reducing the ultimate yield. In both experimental years, it was observed that there was an apprecaible difference between AWA and $\mathrm{ET}_{\text {crop }}$ from crop establishment until the early vegetative stage and from the late vegetative to early flowering stage. The

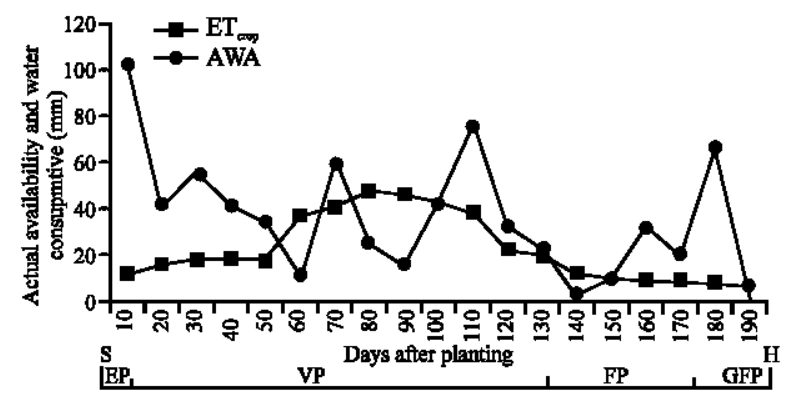

Fig. 6: Relationship between Actual Water Availabilty (AWA) and consumptive water use $\left(\mathrm{ET}_{\text {crop }}\right)$ by sorghum at NIHORT, Ibadan in cropping season 2010 excess of AWA over $\mathrm{ET}_{\text {crop }}$ during these periods implied that Precipitation (P) was in excess of both Potential Evaptranspiration (PE) and $\mathrm{ET}_{\text {crop }}$ and that rainfall was in excess of optimum for crop establishment and inflorescence development.

\section{Sorghum growth characteristics}

Sorghum plant height $(\mathbf{c m})$ season 2009: Shown in Table 1 is the plant height of the 2 sorghum cultivars in monoculture and mixtures of Maize/white Sorghum (MS1), Maize/red Sorghum (MS2), Okra/white Sorghum (OS1), Okra/red Sorghum (OS2) and the combination of Maize/Okra/white Sorghum (MOS1) and Maize/Okra/red Sorghum (MOS2) at 3, 5, 7, 9 and 11 Weeks After Planting (WAP). Table 1 showed that plant height of white Sorghum (S1) in both monoculture and mixtures was statistically difference at 5,7 and 11 WAP while red Sorghum (S2) cultivar showed no significant difference $(\mathrm{p}<0.05)$ at all sampling occasions except at $5 \mathrm{WAP}$ in treatment containing red Sorghum (S2). Sole white Sorghum (S1) ranged from $76.34-229.44 \mathrm{~cm}$, whereas sole red Sorghum (S2) ranged from $70.95-210.66 \mathrm{~cm}$ at 3-11 WAP, respectively.

White Sorghum (S1) in Okra/white Sorghum mixtures (OS1) increased from $59.03 \mathrm{~cm}$ at $3 \mathrm{WAP}$ to $212.78 \mathrm{~cm}$ at 11 WAP while red Sorghum (S2) in Okra/red Sorghum mixtures (OS2), it increased from $59.94-215.78 \mathrm{~cm}$ at 3 and 11 WAP, respectively.

In the mixtures of Maize/white Sorghum (MS1), the values ranged from $53.72-184.78 \mathrm{~cm}$ compared to that in Maize/red Sorghum (MS2) that ranged from 60.61-174.15 $\mathrm{cm}$ at 3-11 WAP, respectively. In maize/okra/sorghum mixtures, sorghum plant height in Maize/Okra/white Sorghum (MOS1) increased from $52.61-166.56 \mathrm{~cm}$ at 3-11 WAP while the values in Maize/Okra/red Sorghum (MOS2) combination increased from $69.41-182.89 \mathrm{~cm}$ at 3 and $11 \mathrm{WAP}$, respectively.

Table 1: Effects of intercropping maize and okra on the Plant (cm) height of the two sorghum genotypes

\begin{tabular}{|c|c|c|c|c|c|c|c|c|c|c|}
\hline \multirow{2}{*}{$\begin{array}{l}\text { Genotypes } \\
\text { Trt }\end{array}$} & \multicolumn{5}{|l|}{$2009 \mathrm{a}$} & \multicolumn{5}{|l|}{$2010 \mathrm{a}$} \\
\hline & $3^{*}$ & $5^{*}$ & $7^{*}$ & $9^{*}$ & $11^{*}$ & $3^{*}$ & $5^{*}$ & $7^{*}$ & $9^{*}$ & $11^{*}$ \\
\hline S1 & 76.34 & 131.69 & 138.89 & 158.11 & 229.44 & 66.75 & 160.22 & 136.22 & 190.02 & 254.00 \\
\hline OS1 & 59.03 & 81.79 & 124.09 & 149.13 & 212.78 & 56.89 & 85.74 & 134.86 & 162.77 & 227.78 \\
\hline MS1 & 53.72 & 89.78 & 117.21 & 134.89 & 184.78 & 55.68 & 86.51 & 124.89 & 139.11 & 165.67 \\
\hline MOS1 & 52.61 & 77.29 & 90.31 & 131.84 & 166.56 & 51.68 & 86.44 & 117.09 & 131.76 & 158.22 \\
\hline $\operatorname{LSD}(0.05)$ & NS & 37.81 & 32.16 & NS & 30.49 & NS & 71.29 & NS & 47.11 & 61.36 \\
\hline & \multicolumn{5}{|l|}{$2009 \mathrm{~b}$} & \multicolumn{5}{|l|}{$2010 \mathrm{~b}$} \\
\hline$\frac{\text { Genotypes }}{\mathrm{S} 2}$ & 70.95 & 99.77 & 130.62 & 202.55 & 210.66 & 64.35 & 91.08 & 135.56 & 199.11 & 250.34 \\
\hline $\mathrm{OS} 2$ & $\begin{array}{l}10.93 \\
59.94\end{array}$ & 90.62 & $\begin{array}{l}150.02 \\
106.41\end{array}$ & $\begin{array}{l}202.53 \\
165.56\end{array}$ & $\begin{array}{l}210.00 \\
215.78\end{array}$ & $\begin{array}{l}54.33 \\
58.37\end{array}$ & 89.63 & $\begin{array}{l}155.50 \\
132.78\end{array}$ & $\begin{array}{l}199.11 \\
181.56\end{array}$ & $\begin{array}{l}230.34 \\
227.67\end{array}$ \\
\hline MS2 & 60.61 & 72.84 & 96.41 & 129.44 & 174.15 & 62.76 & 73.48 & 108.33 & 134.33 & 143.00 \\
\hline $\operatorname{MOS} 2$ & 69.41 & 94.63 & 97.73 & 147.25 & 182.89 & 65.34 & 98.24 & 126.33 & 162.56 & 182.78 \\
\hline $\operatorname{LSD}(0.05)$ & $\mathrm{NS}$ & 16.94 & 24.57 & 29.67 & 34.35 & NS & 20.09 & 22.46 & 33.20 & 40.51 \\
\hline
\end{tabular}

*Weeks after planting; S: Not Significant; M: Maize (Swan-1); O:Okra(NHAe 47-4); maize/okra NHAe 47-4) intercrop; MS1: Maize/white Sorghum Intercrop; MS2: Maize/red Sorghum intercrop; MOS1: Maize/Okra/white Sorghum intercrop; MOS2: Maize/Okra/red Sorghum intercrop; S1: white Sorghum (Farin Dawa) and S2: red Sorghum (Janare); a: Treatments containing white sorghum (Farin Dawa) and b :Treatment containing red sorghum (Janare) 
Agric. J., 6 (3): 92-99, 2011

Table 2: Effects of intercropping okra and maize on the number of leaves of the two sorghum genotypes

\begin{tabular}{|c|c|c|c|c|c|c|c|c|c|c|}
\hline \multirow{2}{*}{$\begin{array}{l}\text { Genotypes } \\
\text { Trt }\end{array}$} & \multicolumn{5}{|c|}{$2009 a$} & \multicolumn{5}{|c|}{$2010 \mathrm{a}$} \\
\hline & $3^{*}$ & $5^{*}$ & $7^{*}$ & $9^{*}$ & $11^{*}$ & $3^{*}$ & $5^{*}$ & $7^{*}$ & $9^{*}$ & $11^{*}$ \\
\hline S1 & 7.78 & 11.66 & 13.44 & 15.11 & 16.11 & 7.56 & 10.89 & 13.11 & 13.64 & 14.78 \\
\hline OS1 & 6.78 & 9.67 & 10.89 & 12.22 & 13.00 & 6.67 & 9.33 & 11.33 & 13.00 & 13.22 \\
\hline MS1 & 6.11 & 8.11 & 8.44 & 10.00 & 10.66 & 6.39 & 7.78 & 8.17 & 10.00 & 11.78 \\
\hline MOS1 & 6.11 & 7.44 & 8.22 & 10.44 & 10.33 & 5.78 & 7.67 & 8.33 & 9.67 & 10.89 \\
\hline \multirow[t]{2}{*}{$\operatorname{LSD}(0.05)$} & 0.77 & 0.85 & 1.26 & 1.10 & 1.09 & 0.81 & 1.39 & 1.58 & 1.74 & 1.98 \\
\hline & \multicolumn{5}{|c|}{$2009 \mathrm{~b}$} & \multicolumn{5}{|c|}{$2010 \mathrm{~b}$} \\
\hline $\mathrm{S} 2$ & 7.78 & 11.78 & 13.33 & 13.78 & 15.99 & 7.45 & 9.56 & 13.00 & 15.00 & 14.33 \\
\hline OS2 & 6.56 & 8.78 & 10.66 & 13.00 & 15.44 & 5.78 & 9.33 & 12.00 & 14.22 & 16.11 \\
\hline MS2 & 6.33 & 8.89 & 9.66 & 11.22 & 12.00 & 5.78 & 7.00 & 7.66 & 10.00 & 9.66 \\
\hline MOS2 & 5.56 & 7.33 & 8.22 & 9.78 & 10.99 & 5.89 & 7.67 & 7.89 & 9.67 & 12.33 \\
\hline LSD $(0.05)$ & 0.58 & 0.91 & 1.38 & 1.61 & 0.97 & 0.86 & 1.47 & 1.13 & 1.92 & 2.26 \\
\hline
\end{tabular}

Season 2010: During this season as shown in Table 1, plant height of sorghum was significantly different at 5,9 and $11 \mathrm{WAP}$ for treatments containing white Sorghum (S1) cultivar and similar trend was observed for treatments containing red Sorghum (S2) except at 3 WAP. Sole white Sorghum (S1) ranged from $76.34-229.44 \mathrm{~cm}$ whereas sole red Sorghum (S2) ranged from 70.95-210.66 $\mathrm{cm}$ at 3-11 WAP, respectively. White Sorghum (S1) in Okra/white Sorghum mixtures (OS1) increased from $56.89 \mathrm{~cm}$ at $3 \mathrm{WAP}$ to $227.78 \mathrm{~cm}$ at $11 \mathrm{WAP}$ while red Sorghum (S2) in Okra/red Sorghum mixtures (OS2) increased from $58.37-227.67 \mathrm{~cm}$ at 3 and $11 \mathrm{WAP}$, respectively.

In the mixtures of Maize/white Sorghum (MS1), the values ranged from $55.68-165.67 \mathrm{~cm}$ compared to that in Maize/red Sorghum (MS2) that ranged from $62.76-143.00 \mathrm{~cm}$ at 3-11 WAP, respectively. In Maize/Okra/ sorghum mixtures, sorghum plant height in Maize/Okra/ white Sorghum (MOS1) increased from 51.68-158.22 $\mathrm{cm}$ at 3-11 WAP while the values in Maize/Okra/red Sorghum (MOS2) combination increased from $65.34-182.78 \mathrm{~cm}$ at 3 and $11 \mathrm{WAP}$, respectively.

\section{Number of leaves per sorghum plant}

Season 2009: Table 2 shows the number of leaves per sorghum plant of the 2 sorghum cultivars in monoculture and mixtures of Maize/white Sorghum (MS1), Maize/red Sorghum (MS2), Okra/white Sorghum (OS1), Okra/red Sorghum (OS2) and the combination of Maize/Okra/white Sorghum (MOS1) and Maize/Okra/red Sorghum (MOS2) at 3, 5, 7, 9 and 11 Weeks After Planting (WAP). Table 2 showed that number leaves per sorghum plant of white Sorghum (S1) in both monoculture and mixtures was statistically difference at all sampled occasions, similarly red Sorghum (S2) cultivar showed significant difference $(p<0.05)$ at all sampled occasions in treatment containing red Sorghum (S2). Number of leaves per plant in sole white Sorghum (S1) ranged from 7.78-16.11 whereas sole red Sorghum (S2) ranged from 7.78-15.99 at 3-11 WAP, respectively. Number of leaves per plant of white
Sorghum (S1) in Okra/white Sorghum mixtures (OS1) increased from 6.78 at 3 WAP to 13.00 at 11 WAP while red Sorghum (S2) in Okra/red Sorghum mixtures (OS2) it increased from 6.56-15.44 at 3 and 11 WAP, respectively. In the mixtures of Maize/white Sorghum (MS1), the values ranged from 6.11-10.66 compared with that in Maize/red Sorghum (MS2) that ranged from 6.33-12.00 at 3-11 WAP, respectively.

In maize/okra/sorghum mixtures, number of leaves in Maize/Okra/white Sorghum (MOS1) increased from 6.11-10.33 at 3-11 WAP while the values in Maize/Okra/red Sorghum (MOS2) combination increased from 5.56-10.99 at 3 and $11 \mathrm{WAP}$, respectively.

Season 2010: Table 2 also showed that number of leaves per plant of sorghum was significantly different at all sampled occasions for treatments containing white Sorghum (S1) cultivar. Similarly, the difference was significant for treatments containing red Sorghum (S2) at all sampled occasions. Number leaves per plant of sorghum in sole white Sorghum (S1) ranged from 7.56-14.78 whereas the values in sole red Sorghum (S2) ranged from $7.45-15.00$ at 3 and 9 WAP, respectively. Number of leaves per plant of white Sorghum (S1) in $\mathrm{Okra} /$ white Sorghum mixtures (OS1) increased from 6.67 at $3 \mathrm{WAP}$ to 13.22 at $11 \mathrm{WAP}$ while the values of red Sorghum (S2) in Okra/red Sorghum mixtures (OS2) increased from 5.78-16.11 at 3 and 11 WAP, respectively. In the mixtures of Maize/white Sorghum (MS1), the values ranged from 6.39-11.78 at 3 and 11 WAP compared to that in Maize/red Sorghum (MS2) that ranged from 5.78-10.00 at 3-9 WAP, respectively. In maize/okra/sorghum mixtures, number of leaves per sorghum plant in Maize/Okra/white Sorghum (MOS1) increased from 5.78-10.89 at 3-11 WAP while the values in Maize/Okra/red Sorghum (MOS2) combination increased from 5.89-12.33 at 3 and 11 WAP, respectively. Generally, both sorghum cultivars perform better in sorghum/okra intercrop than sorghum/maize intercrop in terms of number of leaves per plant. 
Agric. J., 6 (3): 92-99, 2011

Table 3: Panicle length, grain weighthead (g) and grain yield ( $\left(\right.$ ton $\mathrm{ha}^{-1}$ ) of two sorghum genotypes as influenced by intercropping with maize and okra

\begin{tabular}{|c|c|c|c|c|c|c|}
\hline \multirow{2}{*}{$\begin{array}{l}\text { Genotype } \\
\text { Trt }\end{array}$} & \multicolumn{3}{|l|}{$2009 a$} & \multicolumn{3}{|l|}{$2010 \mathrm{a}$} \\
\hline & Panicle length $(\mathrm{cm})$ & Grain weight/head (g) & Grain yield (ton $\left.\mathrm{ha}^{-1}\right)$ & Panicle length $(\mathrm{cm})$ & Grain weight/head(g) & Grain yield (tonha $\mathrm{h}^{-1}$ ) \\
\hline S1 & 46.00 & 69.50 & 1.05 & 71.00 & 65.83 & 0.88 \\
\hline OS1 & 48.67 & 60.50 & 0.84 & 57.80 & 58.83 & 0.80 \\
\hline MS1 & 50.00 & 51.00 & 0.65 & 60.33 & 43.83 & 0.61 \\
\hline MOS1 & 51.00 & 40.17 & 0.45 & 57.17 & 37.16 & 0.42 \\
\hline$\underline{\operatorname{LSD}(0.05)}$ & 1.21 & 10.42 & 0.19 & 13.23 & 6.79 & 0.09 \\
\hline & \multicolumn{3}{|l|}{$2009 \mathrm{~b}$} & \multicolumn{3}{|c|}{$2010 \mathrm{~b}$} \\
\hline$\frac{\text { Genotypes }}{\mathrm{S} 2}$ & 49.67 & 66.07 & 0.94 & 70.73 & 41.23 & 0.91 \\
\hline OS2 & 50.00 & 55.83 & 0.72 & 56.43 & 51.53 & 0.67 \\
\hline MS2 & 51.50 & 39.83 & 0.64 & 52.50 & 37.60 & 0.53 \\
\hline $\operatorname{MOS} 2$ & 52.33 & 37.16 & 0.53 & 55.33 & 23.67 & 0.48 \\
\hline $\operatorname{LSD}(0.05)$ & 1.08 & 9.04 & 0.07 & 13.05 & 28.69 & 0.25 \\
\hline
\end{tabular}

\section{Sorghum yield characters}

Panicle length and grain yield season 2009: Table 3 is on panicle length, grain weight per head and grain yield of the two sorghum genotypes. It is evident from the Table 2 that the grain weight per head and grain yield of the 2 sorghum genotypes intercropped with okra are significantly higher than the corresponding values from maize sorghum intercrop in seasons 2009 and 2010. During season 2009, panicle length of white Sorghum (S1), ranged from $46 \mathrm{~cm}$ for sole white Sorghum (S1) followed by Okra/white Sorghum mixtures (OS1) with $48.67 \mathrm{~cm}$ then Maize/white Sorghum (MS1) with $50 \mathrm{~cm}$ while Maize/Okra/white Sorghum (MOS1) had highest value of $51 \mathrm{~cm}$. The panicle length of red sorghum ranged from $49.67 \mathrm{~cm}$ for sole red Sorghum (S2) followed by red Sorghum/Okra mixture (OS2) that $50.00 \mathrm{~cm}$ then Maize/red Sorghum (MS2) with $51.50 \mathrm{~cm}$ while $\mathrm{Okra} / \mathrm{maize} / \mathrm{red}$ Sorghum mixtures (MOS2) recorded the highest value of $52.33 \mathrm{~cm}$.

Grain yield of white Sorghum (S1), ranged from 1.05 ton ha ${ }^{-1}$ for sole white Sorghum (S1) followed by Okra/white Sorghum mixtures (OS1) with 0.84 ton ha ${ }^{-1}$ then Maize/white Sorghum (MS1) that had 0.65 ton ha $^{-1}$ while Maize/Okra/white Sorghum (MOS1) mixtures had lowest yield of 0.45 ton $\mathrm{ha}^{-1}$. The corresponding values for red Sorghum (S2) combination ranged from 0.94 ton ha ${ }^{-1}$ for sole Sorghum (S2) followed by red Sorghum/Okra mixture (OS2) which had 0.72 ton ha ${ }^{-1}$ then Maize/red Sorghum (MS2) mixture with 0.64 ton ha ${ }^{-1}$ while Okra/Maize/red Sorghum mixtures (MOS2) had lowest yield of 0.53 ton $\mathrm{ha}^{-1}$.

Season 2010: During this season as shown in Table 3, panicle length of treatments containing white Sorghum (S1), ranged from $71.00 \mathrm{~cm}$ for sole white Sorghum (S1) followed by Maize/white Sorghum (MS1) which had $60.33 \mathrm{~cm}$ then Okra/white Sorghum mixtures (OS1) with $57.80 \mathrm{~cm}$ while Maize/Okra/white Sorghum (MOS1) mixtures had lowest value of $57.17 \mathrm{~cm}$. The corresponding values for red sorghum combination ranged from $70.73 \mathrm{~cm}$ for sole red Sorghum (S2) followed by red Sorghum/Okra mixture (OS2) that had $56.43 \mathrm{~cm}$ then Okra/Maize/red Sorghum mixtures (MOS2) which had $55.33 \mathrm{~cm}$ while Maize/red Sorghum (MS2) mixture had lowest values of $52.50 \mathrm{~cm}$.

Grain yield per plot of white Sorghum (S1), ranged from 0.88 ton ha $^{-1}$ for sole white Sorghum (S1) followed by Okra/white Sorghum mixtures (OS1) with 0.80 ton ha $^{-1}$ then Maize/white Sorghum (MS1) which had 0.61 ton ha ${ }^{-1}$ while Maize/Okra/white Sorghum (MOS1) mixtures had lowest value of 0.42 ton $\mathrm{ha}^{-1}$. Correspondingly in red sorghum combination the value ranged from 0.91 ton $\mathrm{ha}^{-1}$ for sole Sorghum (S2) followed by red Sorghum/Okra mixture (OS2) (0.67 ton $\mathrm{ha}^{-1}$ ) then Maize/red Sorghum (MS2) mixture which had 0.53 ton $\mathrm{ha}^{-1}$ while Okra/Maize/red Sorghum mixtures (MOS2) had lowest yield of 0.48 ton $\mathrm{ha}^{-1}$. The findings are in line with the study of Nyambo et al. (1980), Arya et al. (1997), Malik et al. (1998) and Malai and Muthasankaranarayanan (1999) who reported decrease in grain yield of intercropped sorghum and maize compared to sole cropping.

\section{DISCUSSION}

This study confirms, the feasibility of the forestsavanna transition zone of Nigeria for intercropping of the sorghum cultivars; Janare and Farin Dawa with okra (NHAe 47-4) and maize (Suwan-1). The study however, revealed that there are higher prospects and potentials for cultivating okra between the sorghum cultivars; Janare and Farin Dawa than with maize (Suwan-1) in forest-savanna transition zone of Nigeria. Intercropping the two sorghum cultivars (Janare and Farin Dawa) with okra (NHAe 47-4) did not affect significantly the phenological growth stages (i.e., vegetative growth, flowering and fruiting) of the okra and growth and grain yield of associated maize and sorghum cultivars in both 
seasons. This may be probably due to the differences in the stages of growth and development in relation to resources requirement and utilization of both crops. Okra and maize had largely reached physiological maturity before growth of the sorghum was maximal. Similar observation was made by Olasantan $(1999,2001)$ on intercropping okra with cassava. Moreover, sorghum was able to grow properly after okra and maize harvest to fully benefit from full sunlight extra residual soil nutrient and moisture.

Excessive moisture during vegetative growth might reduce the final plant yield considerably by leaching the plant nutrients (Jatzold, 1977). It might also stimulate the population of stem borer lavae (Busseola pussa) within the plant stem and damage the young sorghum grains (Doggett, 1988; Teetes et al., 1983). Yield failure arising from the effect of high water availability as enumerated above was not evident in the study area. Furthermore, the

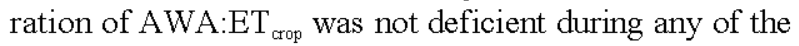
phenological stages of sorghum grown in the study area. However, it was obvious that the amount and distribution of both actual and effective water availability vis-a-vis rainfall during vegetative growth were critical for inflorescence development, quality and quantity of grain yield. Temperature ranges observed fell within the optimum temperature required for sorghum production (Caddel and Weibel, 1971; Downes, 1972; Purseglove, 1972; Quinby et al., 1973).

Downes (1972) indicated that air temperatures $>30^{\circ} \mathrm{C}$ during vegetative stage delayed floral development, particularly initiation of panicle meristem. Therefore, the vegetative phase became longer than usual and the grain yield was reduced. Further review of literature suggested that it is during the period from panicle initiation to anthesis that high temperature leads to reduction in the grain yield of sorghum through its shortening of the period of panicle development (Peacock and Wilson, 1984). In particular, supra-optimal temperatures may hasten flowering (Doggett, 1988) and reduce the length of the period between panicle initiation and anthesis. A reduction in this period caused by high temperature has in some cases been associated with reduced sorghum yields (Ogunlela, 1979). Hence, sorghum based intercropping system should be encourage in view of thermal and moisture advantage of the forest-savanna transition zone.

\section{CONCLUSION}

In this study, the result indicated that the pattern in the variation of principal environmental parameters led to increase in the sorghum yield during the season 2009 and reduction in season 2010 sorghum yield in both sole and mixed crop.

\section{REFERENCES}

Adetunji, A.I., 1993. Growth and yield of intercropped sorghum, Sorghum bicolor and Sunflower Helianthus annum (L.) in semi-arid Nigeria. J. Agron. Crop Sci., 171: 351-357.

Agboola, S.A., 1979. The Agricultural Atlas of Nigeria. Oxford University Press, Oxford.

Arya, R.L., K.P. Niranjan and A. Singh, 1997. Effect of nitrogen and phosphorous on the productivity of grain sorghum (sorghum bicolor) dolichos (Dolichos) intecropping system. Indian J. Agron., 42: 401-404.

Beets, W.C., 1982. Multiple Cropping and Tropical Farming Systems. West View Press Inc., Baulder, Colorado.

Boyer, J.S., 1976. Water Deficit and Photosynthesis. In: Water Deficit and Plant Growth, Kozlowski, T.T. (Ed.). Academic Press, New York, pp: 153-190.

Caddel, J.L. and D.E. Weibel, 1971. Effect of photoperiod and temperature on the development of sorghum. Agron. J., 63: 799-803.

Doggett, H., 1988. Sorghum. 2nd Edn., John Wiley and Sons, New York.

Downes, R.W., 1972. Effect of temperature on the phenology and grain yield of Sorghum bicolor. Aust. J. Agric. Res., 23: 585-594.

Jatzold, R., 1977. Humid month isolines as an aid in agricultural planning. Tubingen Applied Sci. Dev., 9: 140-158.

Jordan, W.R. and C.Y. Sullivan, 1982. Reaction and resistance of grain sorghum to heat and drought. In: Sorghum in the Eighties, House, L.R., L.K. Mughogho and J.M. Peacock (Eds.). ICRISAT, Patancheru, India, pp: 131-142.

Malai, A.S. and A. Muthasankaranarayanan, 1999. Effect of intercropping and weed management practices on growth and yield of integrated sorghum. Madras Agric. J., 86: 43-45.

Malik, M.A. A. Manaf, R. Abar, S. Ahmad and M.A. Hayat, 1998. Feasibility of intercropping mung bean in maize under rainfed condition. Pak. J. Arid Agric., 1: 23-31.

Nyambo, D.B., T. Matimate, A.L. Komba and R.K. Jana, 1980. Influence of plant combination and planting configuration on three cereals (maize, sorghum and millet) intercropped with two legumes (soyabean and green grain). Procedings of the 2nd Symposium on Intercopping in Semi-arid Areas held at Morogoro, Tanizania August, 4-7.

Ogunlela, V.B., 1979. Physiological and agronomic responses of grain sorghum (Sorghum bicolor (L.) Moench) hybrid to elevated night temperatures. Ph.D. Thesis, University of Nebraska, Lincoln. 
Olaniran, O.J. and J.S. Babatolu, 1987. Climate and the growth of sorghum at Kaba, Nigeria. J. Agric. Meteorol., 42: 301-308.

Olasantan, F.O., 1999. Nitrogen fertilization of okra (Abelmoschus esculentus) in an intercropping system with cassava (Manihot esculenta) and maize (Zea mays) in southwestern Nigeria. J. Agric. Sci., 133: $325-334$.

Olasantan, F.O., 2001. Optimum plant populations for okra (Abelmoschus esculentus) in a mixture with cassava (Manihot esculenta) and its relevance to rainy season-based cropping systems in SouthWestern Nigeria. J. Agric. Sci., 136: 207-214.

Peacock, J.M. and G.L. Wilson, 1984. Sorghum. In: The Physiology of Tropical Field Crops, Goldsworthy, P. and N.M. Fisher (Eds.). John Wiley and Sons Ltd., pp: $249-279$.
Purseglove, J.W., 1972. Tropical Crops: Monocotyledons. Language Book Society, Harlow, UK.

Quinby, R., J.D. Hesketh and R.L. Voigt, 1973. Influence of temperature and photoperiod on flora initiation and leaf number in sorghum. Crop Sci., 13: 243-246.

SAS, 2000. The SAS System. SAS Online Doc. HTML Format. Versión 8, SAS Institute, Cary, North Caroline.

Steel, R.G., J.H. Torrie and D.A. Dickey, 1997. Principles and Procedures of Statistics: A Biometrical Approach. 3rd Edn., McGraw-Hill Co., New York, ISBN: 07-060925-x, pp: 666.

Teetes, G.L., K.V.S. Reddy, K. Leuchner and L.R. House, 1983. Sorghum Insect Identification Handbook, Information Bullentin, No. 12. ICRISAT, Patancheru, India.

Whealer, A.W., 1950. Forage and Pasture Crops. Van Nostrand Co. Inc., New York, pp: 639-640. 